\title{
Micro-patterns in grassland vegetation created and sustained by sheep-grazing*
}

\author{
J. P. Bakker', J. de Leeuw ${ }^{1} \&$ S. E. van Wieren ${ }^{2, * *}$ \\ ' Department of Plant Ecology, Biological Center, University of Groningen, P.O. Box 14,9750 AA Haren \\ (Gn), The Netherlands \\ ${ }^{2}$ Institute for Environmental Studies, Free University, P.O. Box 7161, 1007 MC Amsterdam, The Nether- \\ lands
}

Keywords: Grassland, Macro-pattern, Micro-pattern, Pattern stability, Sheep-grazing

\begin{abstract}
An initially uniform Holcus lanatus-dominated sward came partly under hay-making and partly under sheep-grazing. Preferential grazing by sheep resulted in grazing at different intensities giving rise to a macro-pattern of various plant communities. Besides this macro-pattern a micro-pattern developed in the grazed area, which was absent under hay-making. In the micro-pattern short, heavily grazed areas alternated with taller, lightly grazed patches, both having the same species composition. The heavily grazed area was characterized by equal amounts of monocots and dicots. The lightly grazed patches were dominated by Agrostis tenuis, and had a large amount of litter which probably causes the absence of mosses. The protein percentage of green material is higher in the heavily grazed areas than in the lightly grazed patches.

Sequential charting indicated that the micro-pattern was more or less stable. An interaction between the vegetation micro-pattern and grazing patterns is suggested. Heavy grazing results in forage with a high protein content and hence attracts animals. Light grazing results in forage with a relatively low protein content, animals avoid the area and litter accumulates.
\end{abstract}

\section{Introduction}

Large areas of grassland with marginal agricultural value are being abandoned in the Netherlands and elsewhere in Western Europe, e.g. Germany (Ellenberg, 1978). Continuation of agricultural practices is usually too labour-intensive to be economically feasible in view of the low yields. Left to run wild, former hay-fields may turn into swards with litter accumulation, communities of tall grasses, sedges and forbs, while former pastures may turn into woodland (Ellenberg, 1978). In the Netherlands such land is often acquired by the State or by private organizations for landscape - or nature

\footnotetext{
* Nomenclature follows Heukels \& van Ooststroom(1977) Flora van Nederland.
}

** Mrs J. O'Brien corrected the English text conservation purposes, which help to prevent the above-mentioned processes.

A major objective has been to reduce the residual effects of fertilizer applications in order to increase species and community diversity (Research Institute for Nature Management, 1979; P. Bakker, 1979). This goal may be persued by hay-making or by grazing. Grazing at different intensities is considered an advantage for production of greater vegetational differentiation (Klapp, 1965; Oosterveld, 1975; Harper, 1977). Grazing at a relatively low stocking rate leads to variation in soil compaction and heterogeneous removal of plant material due to selectivity of the grazing animals. This produces a kind of diversity hay-making cannot render.

Selectivity in grazing is a well-known phenomenon. Charles et al. (1977) found in Scottish uplands that deer preferred feeding on grasslands rather than heaths and bogs. Wielgolaski in Nor- 
way (1976) and Job \& Taylor (1978) reached similar conclusions for upland sheep-grazing. Hunter (1962) demonstrated selectivity with various sheepgrazing intensities on different upland grassland communities in Scotland. Klötzli (1965) showed that in grassland in Switzerland roe deer prefer Arrhenatheretum meadows. With respect to scale, we call the above selectivity patterns macro-patterns.

Besides selectivity on the vegetation type level there is preference or avoidance of species resulting in a mosaic of taller tufts interspersed with shorter vegetation. With respect to scale, we call this a micro-pattern. Hunter (1962) mentioned clumps of Juncus effusus and Deschampsia cespitosa in moist grassland. Nicholson et al. (1970) noticed Nardus stricta tussocks in uplands. Bakker \& Ruyter (1981) found clumps of Juncus maritimus on a salt marsh. Often, descriptions of this kind are the result of a single study and no comparison is made with the previous situation of the area.

The present paper deals with (i) vegetational succession originating from an initially uniform sward under hay-making and grazing of various intensities, (ii) the stability of micro-patterns.

\section{Methods}

The fenced-in study area, the Westerholt (Province of Drenthe, The Netherlands, $53^{\circ} 01^{\prime} \mathrm{N}$, $6^{\circ} 11^{\prime} \mathrm{E}$ ) comprises 3 ha of Calluna vulgaris/Erica tetralix heathland, 2 ha of deciduous woodland (Betula spp. and Salix spp.) and 6 ha of pasture land which was originally heathland but ploughed and sown to grass in the 1950's. Until 1972 the grassland was fertilized, and used for hay production. The aftermath was grazed by cattle. No fertilizers have been applied since 1971. In October 1972 sheep were introduced to graze the whole area at an average stocking rate of 3 sheep/ha. Twenty-five sheep grazed during the period July-December and 40 between January-July. In the spring of 1980 the sheep were replaced by a new flock. Since 1980 the area has received a winter rest period of 2 months from grazing.

In 1972, before grazing started, a number of permanent quadrats (p.q.'s) each $2 \times 2 \mathrm{~m}$, were laid on the uniform moist grassland then dominated by Holcus lanatus, and recorded annually using the
Braun-Blanquet approach. Litter accumulation was used according to Job \& Taylor (1978) to determine grazing intensity. Three grazing intensity classes for the p.q.'s were applied: lightly grazed $>70 \%$ litter cover, heavily grazed with $<30 \%$, and intermediate grazing. The amount of litter was determined in February 1982, because at the end of the winter period differences between heavily and lightly grazed areas are maximal. Litter cover and thickness were positively correlated $(r=0.909)$ according to Veldman (1983).

A mosaic of taller tufts interspersed with shorter vegetation appeared only in the grazed area. This mosaic was roughly quantified in July 1982 in $6 \mathrm{~m}$ transects by determining the canopy height at $15 \mathrm{~cm}$ intervals using a disc $(\varnothing 15 \mathrm{~cm}, 19 \mathrm{~g})$ that could be dropped down a calibrated stick. Height class patterns were determined using a test for trend.

Fixation of the mosaic was also determined. A detailed charting of the mosaic was made in October 1979 in one $\left(10 \times 10 \mathrm{~m}^{2}\right)$ site. Areas with a canopy height $\leqslant 5 \mathrm{~cm}$ and little litter accumulation were recorded as heavily grazed, patches with a canopy height $\geqslant 10 \mathrm{~cm}$ and more litter accumulation as lightly grazed. Due to the sharp boundaries an intermediate height class was absent. The charting was repeated several times until the autumn of 1982. The map patterns were compared using an overlay with 200 randomly placed points. A chisquare based point correlation test was used to determine their correlation.

If the mosaic was fixed, differences in soil compaction among heavily grazed areas and lightly grazed patches are expected. Soil resistance was recorded $(n=20)$ with a soil penetrometer after a very wet period, under waterlogged conditions.

Species abundance was quantified on a dry weight basis. The aerial biomass was clipped in five cores of $78.5 \mathrm{~cm}^{2}$ in heavily grazed areas and lightly grazed patches at surface level and separated into live and dead portions. Crude protein $\%$ was measured in the tops of the live portions.

\section{Results}

Table 1 shows the species composition and mean abundance in 1981 in p.q.'s under hay-making and various grazing intensities. In the heavily grazed p.q.'s, the Holcus lanatus group, including nearly 
Table 1. Species composition and mean cover, originating from an initially uniform sward in 1972 at hay-making and various grazing intensities; (A) heavily grazed (area covered by litter $\leqslant 30 \%$ ); (B) moderately grazed ( $>70 \%$ area covered by litter $>30 \%)$; (C) lightly grazed (area covered by litter $\geqslant 70 \%$ ). (I) species with largest cover percentage at heavy grazing intensity; (II) species with largest cover percentage at moderate grazing intensity; (III) species with largest cover percentage at light grazing intensity; (IV) species indifferent with respect to grazing intensity.

\begin{tabular}{|c|c|c|c|c|c|c|c|c|}
\hline \multirow{2}{*}{$\begin{array}{l}\text { Management practice } \\
\text { Year } \\
\text { Number of permanent plots }\end{array}$} & \multicolumn{4}{|c|}{ Beginning situation } & \multicolumn{3}{|c|}{ Grazing } & \multirow{2}{*}{$\begin{array}{l}\text { Hay- } \\
\text { making } \\
1981 \\
n=4\end{array}$} \\
\hline & $\begin{array}{l}1972 \\
n=4\end{array}$ & $\begin{array}{l}1972 \\
n=10\end{array}$ & $\begin{array}{l}1972 \\
n=14\end{array}$ & $\begin{array}{l}1972 \\
n=4\end{array}$ & $\begin{array}{l}\text { A } \\
1981 \\
n=4\end{array}$ & $\begin{array}{l}\text { B } \\
1981 \\
n=10\end{array}$ & $\begin{array}{l}C \\
1981 \\
n=14\end{array}$ & \\
\hline \multicolumn{9}{|l|}{ I } \\
\hline Holcus lanatus & 42 & 48 & 42 & 45 & 22 & 24 & 8 & 1.5 \\
\hline Lolium perenne & 10 & 9 & 16 & 18 & 6 & 2.9 & 0.7 & \\
\hline Poa trivialis & & 0.4 & 3.0 & 0.3 & 2.0 & 1.8 & 0.9 & 0.3 \\
\hline Cynosurus cristatus & & & & & 0.5 & 0.2 & 0.3 & 0.3 \\
\hline Alopecurus geniculatus & 2.5 & 0.6 & 0.8 & & 0.5 & 0.3 & & \\
\hline Festuca pratensis & & 1.8 & 1.2 & & 0.3 & 0.2 & 0.1 & \\
\hline Ranunculus repens & & 1.3 & 1.5 & 1.0 & 5 & 7 & 2.6 & 7 \\
\hline Trifolium repens & 2.0 & 0.6 & 1.4 & 3.0 & 8 & 5 & 1.2 & 0.5 \\
\hline Sagina procumbens & & & 0.2 & & 0.8 & 0.4 & 0.1 & \\
\hline Cardamine pratensis & & 0.2 & 0.8 & 0.3 & 0.8 & 0.7 & 0.3 & 0.8 \\
\hline Leontodon autumnalis & 0.3 & 0.2 & 1.7 & 3.0 & 13 & 6 & 3.0 & 8 \\
\hline Bellis perennis & 3.0 & 1.2 & 0.8 & 1.5 & 3.5 & 1.1 & 0.6 & 0.3 \\
\hline Hypochaeris radicata & 0.3 & & & & 3.0 & 3.3 & 0.8 & 1.8 \\
\hline Plantago major & 0.8 & 0.7 & 0.8 & 1.5 & 3.0 & 0.6 & 0.1 & \\
\hline \multicolumn{9}{|l|}{ II } \\
\hline Elytrigia repens & 5 & 2.0 & 0.2 & & & 1.0 & & \\
\hline Ranunculus acris & & 1.2 & 1.2 & 2.0 & 1.5 & 9 & 1.8 & 5 \\
\hline Taraxacum spec. & 2.5 & 3.8 & 3.2 & 3.0 & 1.8 & 2.5 & 1.3 & 4.5 \\
\hline Rumex acetosa & 1.5 & 1.6 & 0.5 & & 1.3 & 1.6 & 1.4 & 6 \\
\hline Cerastium fontanum & 3.0 & 2.6 & 1.7 & 2.0 & 1.0 & 1.3 & 0.8 & 0.8 \\
\hline Rumex acetosella & & 0.4 & & & & 0.5 & 0.2 & \\
\hline Plantago lanceolata & & & & & & 0.5 & 0.1 & 0.3 \\
\hline Cirsium arvense & & 0.1 & & & & 0.5 & 0.2 & \\
\hline Cirsium vulgare & & & 0.1 & & & 0.1 & & \\
\hline \multicolumn{9}{|l|}{ III } \\
\hline Agrostis tenuis & & & 2.4 & & 27 & 25 & 60 & 15 \\
\hline Poa pratensis & 7 & 7 & 10 & 3.5 & 1.3 & 1.4 & 2.5 & 2.0 \\
\hline Phleum pratense & 2.5 & 3.8 & 2.6 & 2.0 & & 0.4 & 0.4 & 2.0 \\
\hline Cirsium palustre & 0.5 & 0.4 & 0.4 & & 2.0 & 3.2 & 3.5 & 0.3 \\
\hline Lotus uliginosus & & & 0.3 & & & 0.6 & 1.5 & \\
\hline Galium palustre & & 0.1 & & & 0.2 & & 0.2 & 0.5 \\
\hline \multicolumn{9}{|l|}{ IV } \\
\hline Agrostis stolonifera & & & & & 0.3 & 0.1 & 0.2 & \\
\hline Anthoxanthum odoratum & & & & & 1.0 & 1.5 & 1.2 & 15 \\
\hline Juncus effusus & 0.3 & & 1.8 & 1.5 & 1.3 & 0.5 & 1.9 & 3.3 \\
\hline Juncus subuliflorus & & & & & 0.5 & 0.1 & 0.3 & \\
\hline Juncus articulatus & & & 0.2 & & 0.3 & & 0.1 & \\
\hline Juncus acutiflorus & & & 0.2 & & & & 1.5 & \\
\hline Eleocharis palustris & & & 0.2 & & & & 0.1 & \\
\hline Carex nigra & & & 4.5 & 3.0 & & 0.1 & 3.6 & \\
\hline Dactylis glomerata & & 0.6 & & & & 0.2 & & \\
\hline Ranunculus flammula & & & 0.5 & & & & 0.1 & \\
\hline Epilobium palustre & & & 0.1 & & & & 0.1 & \\
\hline Achillea ptarmica & & & 0.2 & & & & 0.1 & \\
\hline
\end{tabular}

Species appearing at one grazing intensity: Carex ovalis, Agrostis canina, Holcus mollis, Achillea millefolium, Achillea ptarmica, Galium mollugo, Polygonum persicaria, Calluna vulgaris; species appearing at one grazing intensity and hay-making: Luzula campestris, Prunella vulgaris; species appearing at hay-making: Rhinanthus serotinus; species disappearing: Poa annua, Bromus mollis, Juncus bufonius, Glyceria fluitans, Betula pubescens, Angelica sylvestris, Stellaria graminea, Stellaria media, Polygonum hydropiper; species only maintaining at hay-making: Trifolium dubium, Trifolium pratense. 
all rosette plants, reached largest abundance. The Elytrigia repens group was relatively abundant at intermediate grazing intensity. The Agrostis tenuis group reached largest abundance in the lightly grazed p.q.'s. The Agrostis stolonifera group reacted indifferently with respect to grazing intensity. Hay-making resulted in deviating abundances of the species concerned.

The same subsets of p.q.'s had been used in determining the abundance of species in 1972 at the start of the experiment. Table 1 shows an initially uniform sward in the moist grassland area, before grazing and hay-making started.

Figure 1 shows the canopy height along transects in the grazed and hayed area in July 1982, developed from the sward. The vegetation in the haymaking area is on average taller than in the grazing area. The sequence of points is random at hay-making, whereas the sequence is cyclical at grazing $(p<$ 0.02 ). Thus with grazing a mosaic of taller tufts interspersed with shorter vegetation has developed. The diameter of the tufts can range from $0.5 \mathrm{~m}$ to a maximum of $3 \mathrm{~m}$ (Fig. 1). It should be noted that these tufts are often smaller than the size of the p.q.'s. The appearance of the micro-pattern can also be derived from the photograph in Figure 2 comparing part of the study area inside and outside the fence in 1982. The vegetation has a uniform appearance on the hay-making side of the fence, whereas a mosaic exists in the grazed area.

Figure 3 reveals the micro-pattern in a $10 \times 10 \mathrm{~m}^{2}$ area in 1979 (Fig. 3A) and in 1981 (Fig. 3B). Clearly, centers exist both in the lightly grazed taller canopy and in the heavily grazed lower canopy as well as an intermediate zone with a mixture of the two types (Fig. 3C). It is noticeable from the chartings that the patterns resemble each other more at a short interval of charting than at a longer interval (Fig. 4). Moreover, after two years the resemblance does not diminish any further and remains significant $(p<0.05)$. Hence it is concluded that the micro-pattern found does not randomly change from year to year, but was fixed under the grazingregime. Another indication of the constancy of the mosaic is the great difference in soil resistance among heavily grazed areas $11.5( \pm 2.3) \mathrm{kg} . \mathrm{cm}^{-2}$, as compared to the lightly grazed patches $5.5( \pm 0.7)$ $\mathrm{kg} . \mathrm{cm}^{-2}$.

Species compositions in the short, heavily grazed areas and the taller, lightly grazed patches are listed

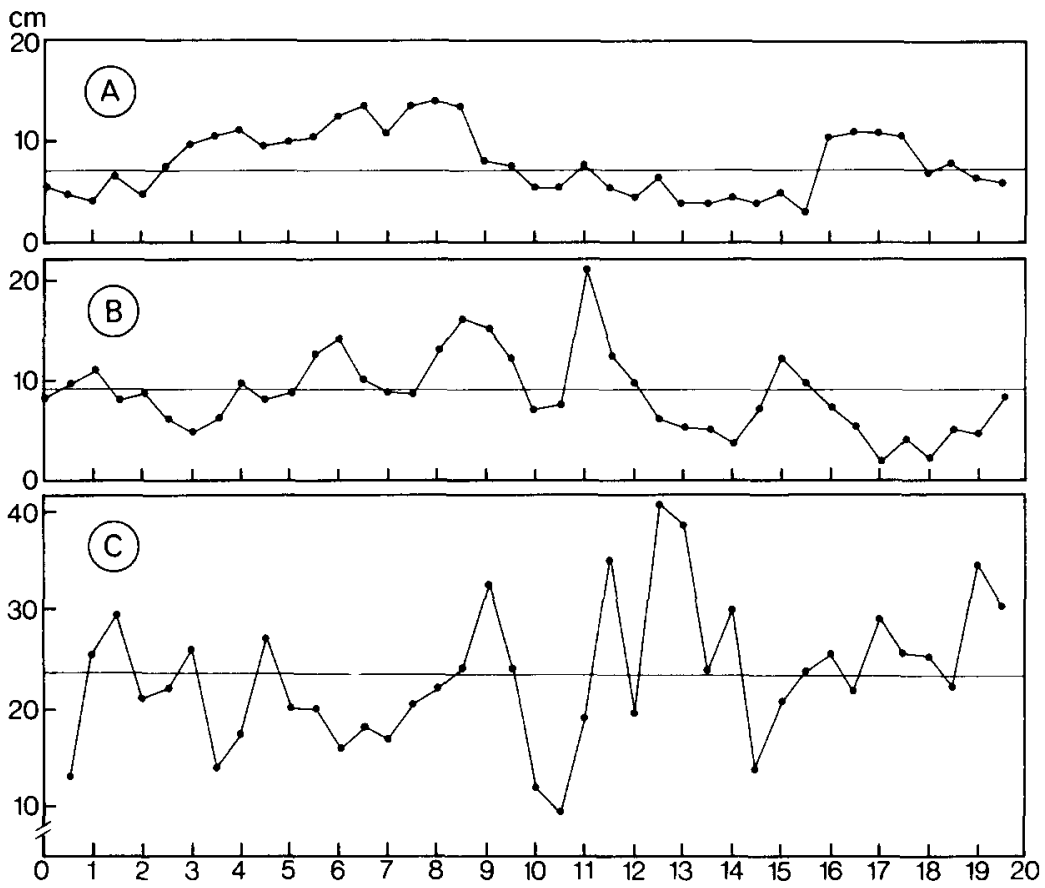

Fig. 1. Canopy height in pasture (A and B) and in hay-field (C) in July 1982 in $20 \mathrm{~m}$ transects at $50 \mathrm{~cm}$ intervals in the hay-field and in $6 \mathrm{~m}$ transects at $15 \mathrm{~cm}$ intervals in the pasture. 

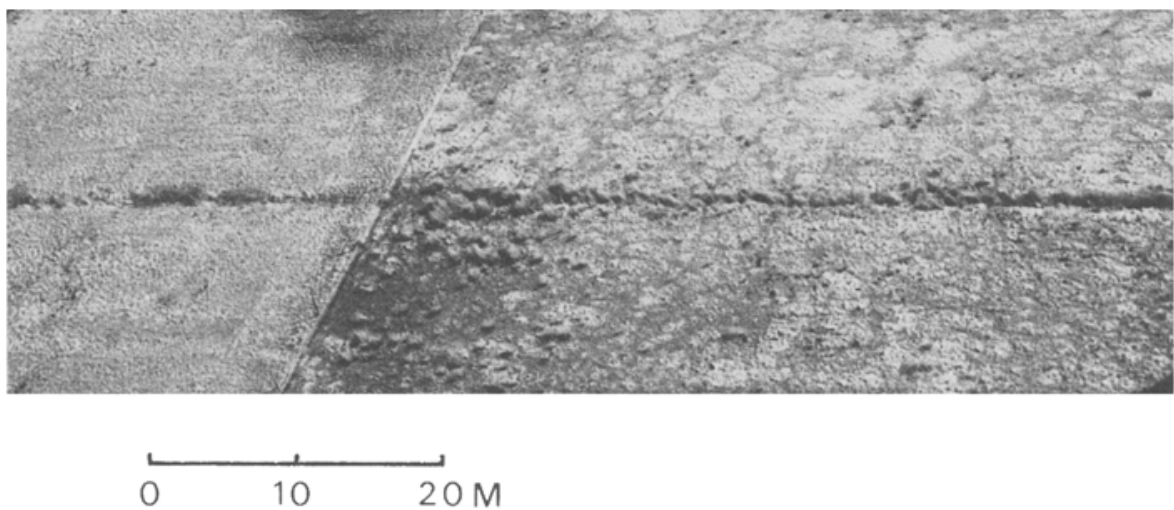

Fig. 2. Aerial view of the study area ten years after the start of the experiment (April 1982). Hay-making is carried out on the left side of the fence, grazing is done on the right side of the fence. The vegetation had the same uniform appearance on either side of the fence in 1972 . A marked patchy appearance can be discovered in the grazed area in 1982; the lightly grazed patches are lightly coloured because of dead organic material, the heavily grazed areas are dark.

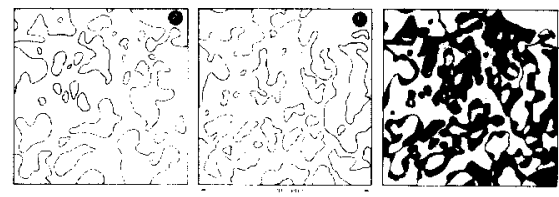

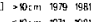

-

Fig. 3. Micro-pattern in a dry grassland site $(10 \times 10 \mathrm{~m})$ as developed after seven years (A: October 1979) and after nine years (B: August 1981) of sheep-grazing. White $=$ canopy $\leqslant 5 \mathrm{~cm}$ high, hatched $=$ canopy $\geqslant 10 \mathrm{~cm}$ high, black = canopy high in 1979 and low in 1981 or the reverse.

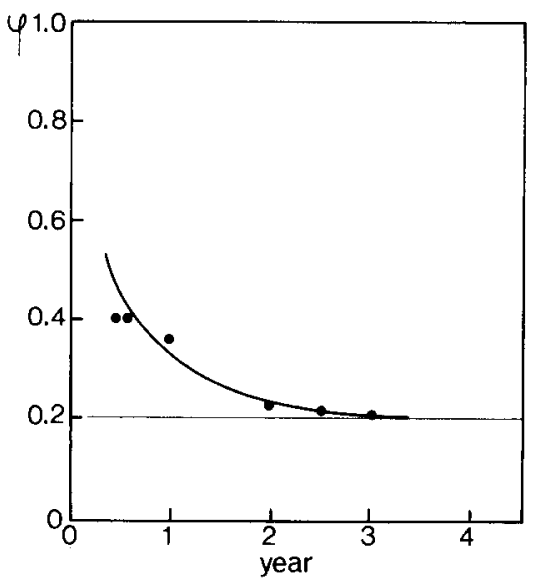

Fig. 4. Correlations between subsequent micro-pattern chartings between October 1979 and October 1982. The level of significance $(p<0.05)$ is indicated. in Table 2. They differ only slightly, but the abundances of occurring species differ considerably. The amount of Agrostis tenuis in the lightly grazed patches is striking; it represents most of the green aerial biomass of the monocots. The dry weight amount of dicots in the lightly grazed patches equals that of the heavily grazed areas. Due to the small amount of green aerial biomass the dicot biomass percentage is relatively large in the heavily grazed areas. The larger amount of dead plant material in the lightly grazed patches than in the heavily grazed areas indicates litter accumulation in the former. It probably causes the absence of mosses. The heavily grazed areas reveal a higher crude protein \% than the lightly grazed patches.

The heavily grazed areas resemble the p.q.'s under high grazing intensity, whereas the lightly grazed patches resemble the p.q.'s under light grazing intensity (Table 1). Thus species composition and abundance, as well as litter accumulation on the scale of the whole grassland area (macro-pattern) can also be found in micro-patterns within the p.q.'s.

\section{Discussion}

\section{Macro-patterns}

Hunter(1962), Klötzli(1965), Wielgolaski(1976), Charles et al. (1977) and Job \& Taylor (1978) found macro-patterns in plant communities dominated by 
Table 2. Live and dead aerial biomass $\left(\mathrm{gdw} . \mathrm{m}^{-2}\right)$ and percentage crude protein in heavily grazed areas and lightly grazed patches, measured in sample plots of $78.5 \mathrm{~cm}^{2}(n=5)$ in September 1981 .

\begin{tabular}{|c|c|c|}
\hline Number of species & $\begin{array}{l}\text { Heavily grazed } \\
11\end{array}$ & $\begin{array}{l}\text { Lightly grazed } \\
11\end{array}$ \\
\hline Agrostis tenuis & $15.4 \pm 3.2$ & $306.6 \pm 36.7$ \\
\hline Holcus lanatus & $15.7 \pm 5.6$ & $71.7 \pm 14.6$ \\
\hline Anthoxanthum odoratum & $13.6 \pm 4.8$ & $5.6 \pm 3.6$ \\
\hline Poa pratensis & $5.6 \pm 1.9$ & $7.0 \pm 1.8$ \\
\hline Cynosurus cristatus & $0.1 \pm 0.1$ & $4.4 \pm 3.8$ \\
\hline Lolium perenne & - & $1.1 \pm 1.1$ \\
\hline Festuca rubra & - & $0.9 \pm 0.8$ \\
\hline Total monocots & $50.4 \pm 7.2$ & $397.3 \pm 44.6$ \\
\hline Trifolium repens & $19.2 \pm 4.0$ & $11.1 \pm 2.6$ \\
\hline Ranunculus acris & $3.7 \pm 1.1$ & $15.9 \pm 8.2$ \\
\hline Leontodon autumnalis & $27.5 \pm 8.0$ & $36.4 \pm 18.9$ \\
\hline Taraxacum spec. & $0.5 \pm 0.3$ & - \\
\hline Hypochaeris radicata & $5.5 \pm 4.4$ & - \\
\hline Trifolium pratense & $0.3 \pm 0.3$ & - \\
\hline Stellaria media & - & $0.5 \pm 0.5$ \\
\hline Total dicots & $56.7 \pm 9.8$ & $63.9 \pm 24.6$ \\
\hline Green aerial biomass & $107.1 \pm 10.9$ & $461.2 \pm 31.8$ \\
\hline dead plant material & $93.2 \pm 6.6$ & $393.1 \pm 66.1$ \\
\hline mosses & $10.6 \pm 4.7$ & - \\
\hline percentage monocots & $47.0 \pm 5.4$ & $86.1 \pm 6.7$ \\
\hline $\begin{array}{l}\text { protein percentage of } \\
\text { green material }\end{array}$ & $19.8 \pm 1.2$ & $15.0 \pm 0.9$ \\
\hline
\end{tabular}

different species, because preferential grazing by sheep results in grazing at different intensities. Thus the grazing intensities reflect the preference or avoidance for dominant species. This holds also for the Westerholt study area where the improved grassland sections are preferred during the summer and the heathland sections during the winter. $\mathrm{Mo}$ reover, within the improved grassland sections sheep prefer dominating Holcus lanatus over Juncus effusus (Bakker et al., 1983).

In the above situations grazing probably took place for long periods, maybe centuries, so the vegetation composition at the beginning of the grazing and a possible earlier development of the macropattern is not known. The plant communities mentioned all occur on particular soil types. Thus the macro-patterns of plant communities and hence the macro-patterns of grazing intensities reflect the affinities between vegetation types and soil types. It can be concluded that the observed patterns of grazing intensity are imposed by the patterns of plant communities.

Little information is available on the constancy in the above-mentioned grazing patterns. Hunter (1962) measured that preference among sward types varied seasonally in the same way during three years of observation. He mentioned no influence of the grazing pattern upon the plant community pattern. In the Westerholt study area Bakker et al. (1983) found that the annual occupancy patterns of the sheep had been fairly constant from 1974 1978. Moreover, in this case it is known that the grazing pattern influences the plant community macro-pattern. The initially uniform Holcus lanatus sward diverged into several new communities corresponding with grazing intensity or occupancy patterns of the sheep. Grassland sections with greater occupancy contained the shorter vegetation, higher rosette plant cover and, to a lesser extent, greater persistence of Lolium perenne (Bakker $e t$ al., 1983). These results accord with those presented in Table 1.

\section{Micro-patterns}

Hunter (1962), Nicholson et al. (1970) and Bakker \& Ruyter (1981) found micro-patterns in grazing intensity due to avoidance of species. Bürkle (1980) mentioned an increase of Agrostis tenuis, Deschampsia cespitosa and Nardus stricta within four years under continuous grazing in Germany, but gives no information about pattern development.

Nicholson et al. (1970) described the development in a Nardus stricta, Festuca ovina, Molinia caerulea, Anthoxanthum odoratum sward of Nardus stricta tussocks under heavy grazing (2.5 sheep per ha). Single plants or clumps of Anthoxanthum odoratum or young Molinia caerulea shoots provided the loci which were initially moderately grazed. As grazing increased around the edges of these patches, material tended to be taken less selectively, close grazing of the initial centers and expanding outwards produced a patchwork of closegrazed areas. The close-grazed areas eventually joined and grazing pressure over the entire area became relatively uniform, except for isolated areas that were partly rejected - usually Nardus stricta tussocks.

The constancy of the micro-patterns revealed by the above authors seems likely, because the avoi- 
dance of species will remain. Hunter (1962) revealed that the taller tufts consist of one avoided species by mentioning that sheep graze on the grass between the Juncus effusus clumps. It can be concluded that the micro-patterns in grazing had been determined by the presence of isolated tussocks or clumps of individuals of avoided species in the canopy before grazing started.

At the Westerholt study area, small clumps of Juncus effusus exist. However, the taller tufts of lightly grazed patches in the micro-pattern do not consist of one single species, but have nearly the same species composition as the heavily grazed areas (Table 2). Since especially avoided species are absent, it is suggested that random grazing in the initially uniform Holcus lanatus sward at the beginning of the grazing experiment initiated the development of the micro-patterns.

The - artificial - development of heavily grazed areas and lightly grazed patches was also noticed in uniform heathland by Grant \& Hunter (1968). They burnt small areas at various intervals and measured sheep preference for the recently burnt areas. Norman (1957) reported patchiness within two years in a chalk pasture trial in the United Kingdom brought about by under-grazing. Van Leeuwen \& van der Maarel (1971) described a grassland-scrub mosaic in the dunes with abrupt borders between the two components, due to rabbit-grazing. When rabbitgrazing stopped the differentiated micro-pattern became replaced by a coarser one.

A micro-pattern with large abiotic differences and differences in species composition among heavily grazed areas and lightly grazed patches was mentioned by Pigott (1956) and Regnell (1980). They described peaty tussocks on a calcareous and loamy subsoil, but their development was uncertain. The development of tussocks in marshes on the slopes of Upper Teesdale was considered to be the residual parts of an initially continuous turf, split by trampling cattle and subsequent water erosion (Pigott, 1956). The tussocks in S Sweden had perhaps developed in a similar way from continuous turf in the hay-meadows of the 18th century. Anyway, these tussocks do not seem to be generally dependent on the growth form of certain species, e.g. Molinia caerula or Schoenus nigricans (Regnell, 1980). Important abiotic differences among tussocks and depression are found. This finding in combination with the age of the tussocks explains their diverging composition.
Evidently the grazing and trampling of cattle is essential to maintain the tussocky vegetation in the calcareous marshes. In the ungrazed parts almost nothing can be seen of tussocks. On the other hand, tussocks once formed perpetuate and govern the trampling pattern of the cattle. Out of 117 'steps', observed on freely grazing cattle, 106 were placed in depressions, 5 in an intermediate position, and only 6 on tussocks (Regnell, 1980). It also lead to a considerable compactness in the depressions, as was found in the heavily grazed areas in the Westerholt study area. Such a positive correlation between trampling and soil resistance is well documented (Langlands \& Bennett, 1973a; Crawford \& Liddle, 1977; Witschi \& Michalk, 1979; BülowOlsen, 1980).

Interaction between vegetation patterns and grazing patterns

A fixed vegetation pattern results in micro-climatological differences among heavily grazed areas and lightly grazed patches. Differing conditions (as demonstrated by the soil resistance), may subsequently affect germination and seedling establishment. For instance, a dense sward prevents seedling establishment of Plantago major (Blom, 1977), and Bellis perennis, Trifolium repens, Rumex acetosella (Harper, 1977), and Taraxacum sp. (Mølgaard, 1977) develop much better in a periodically cut than in an undisturbed sward. Eventually the species composition of heavily grazed areas and lightly grazed patches might diverge; the question is at what time interval?

Species diversity is expected to remain rather low due to litter accumulation at the lightly grazed patches (Grime, 1979). However, species diversity will remain low at the heavily grazed areas due to the high frequency of disturbance (Huston, 1979).

Once formed, the mosaic of heavily grazed areas and lightly grazed patches probably governs the grazing pattern. Grazing and litter accumulation in lightly grazed patches were negatively correlated under sheep-grazing in Wales and in Scotland according to Job \& Taylor (1978) and Hodgson \& Grant (1981), and under cattle grazing in Idaho according to Leege et al. (1981). Bülow-Olsen (1980) showed that cattle grazing reduced the amount of dead plant material from 4 to $1 \mathrm{t} \cdot \mathrm{ha}^{-1}$ within 2-3 years in Deschampsia flexuosa-dominated grassland in Denmark. Standing dead mate- 
rial reportedly discouraged utilization of green forage by deer, and both cattle and deer preferred sites where litter was removed by burning or cutting in an Agropyron spicatum-dominated sward in the United States (Willms et al., 1980). In a uniform Phalaris/Trifolium pasture in Australia, Langlands \& Bennett (1973b) found that the ability of sheep to select green material of high digestibility was impaired at low stocking rates. This was due to the dilution of green forage by dead material which had not been consumed in previous years.

Repeated defoliation in the heavily grazed areas stimulates tillering (Harper, 1977; Witchi \& Michalk, 1979). Prevention of flowering and subsequent regrowth of Agrostis tenuis provides a higher level of digestibility than found in flowering plants and hence will stimulate further grazing (Black, 1957). The protein content differences (Table 2) can be attributed to a greate proportion of young leaves, which generally have a high protein content and a relatively low percentage of cell wall components (Arnold, 1964; Stobbs, 1973; Mattson, 1980). The sheep preference for recently burnt heathland areas was correlated with a high $\mathrm{N}$ content of heather leaves (Grant \& Hunter, 1968). Frame \& Hunt (1971) found that in grass swards the frequently defoliated herbage had a higher percentage of crude protein than that of other treatments. Bürkle (1980) found more crude protein when the remainder was mown than in the part not cut of a continuously grazed area. More young leaves and a higher leaf/stem ratio result in a higher preference (Davies, 1925) probably due to a higher digestibility of forage (Stobbs, 1973).

The present study demonstrates that Agrostis tenuis is hardly grazed in lightly grazed patches, but heavily exploited in heavily grazed areas, so its preference might depend on the condition in which sheep keep their forage. Nicholson et al. (1970) found that the unpalatable species Nardus stricta is eaten in a dense mass of interwoven leaves and shoots, but avoided when Nardus tufts were fairly isolated. Thus the 'preferred species' concept should be treated with caution. Agrostis tenuis and Holcus lanatus have a low forage value when compared with Lolium perenne, but a high value with respect to Festuca ovina (Klapp, 1965). Preference should be considered against the background of the choice the foraging animal can make (Davies, 1925). For a better understanding of micro-pattern development it may be required to determine crude protein, percentage of cell wall components, digestibility for the same species under different grazing pressures. Experiments involving exclusion of the heavily grazed areas and cutting the lightly grazed patches are in progress.

It can be concluded that the heavily grazed areas have a higher forage quality than the lightly grazed patches. This implies another level of forage selectivity than the vegetation type level (Wielgolaski, 1976; Charles et al., 1977; Job \& Taylor, 1978). There is a preference for specific sites with a high forage quality. Like good farmers the sheep maintain these sites by their feeding strategy. Heavily grazing results in a high protein content of the forage and hence attracts animals again. Light grazing results in a relatively low protein content of the forage, with litter accumulation and subsequent avoidance by the animals.

\section{References}

Arnold, G. W., 1964. Factors within plant associations affecting the behaviour and performance of grazing animals. In: D. J. Crisp (ed.). Grazing in Terrestrial and Marine Environments, pp. 133-154. Blackwell, Oxford.

Bakker, J. P. \& Ruyter, J. C., 1981. Effects of five years of grazing on a salt-marsh vegetation - a study with sequential mapping. Vegetatio 44: 81-100.

Bakker, J. P. \& Bie, S. de, Dallinga, J. H., Tjaden, P. \& Vries, Y. de, 1983. Sheep grazing as a management tool for heathland conservation and regeneration in the Netherlands. J. Appl. Ecol. 20: 541-560.

Bakker, P. A., 1979. Vegetation science and nature conservation. In: M. J. A. Werger (ed.). The Study of Vegetation, pp. 247-288. Junk, The Hague.

Black, J. S., 1957. The digestibility of indigenous hill pasture species. Rep. Hill Farming Res. Org. 4: 33-37.

Blom, C. W. P. M., 1977. Effects of trampling and soil compaction on the occurrence of some Plantago species in coastal sand dunes. II. Trampling and seedling establishment. Oecologia Plantarum 12: 363-381.

Bülow-Olsen, A., 1980. Nutrient cycling in grassland dominated by Deschampsia flexuosa (L.) Trin. and grazed by nursing cows. Agro-Ecosystems 6: 209-220.

Bürkle, A., 1980. Vegetationskundliche, weidewirtschaftliche und strukturelle Untersuchungen zur Koppelschafhaltung im Allgau Bayer. Landw. Jahrb. 57: 159-346.

Charles, W. N., McCowan, D. \& East, K., 1977. Selection of upland swards by Red Deer (Cervus elaphus L.) on R hum. J. Appl. Ecol. 14: 55-64.

Crawford, A. K. \& Liddle, M. J., 1977. The effect of trampling on neutral grassland. Biol. Cons. 12: 135-142.

Davies, W., 1925. The relative palatability of pasture plants. J. Min. Agric. 32: 106-116. 
Ellenberg, H., 1978. Vegetation Mitteleuropas mit den Alpen. Ulmer, Stuttgart.

Frame, J.\& Hunt, 1. V., 1971. The effects of cutting and grazing systems on herbage production from grass swards. $\mathrm{J}$. Br. Grassl. Soc. 26: 163-171.

Grime, J. P., 1979. Plant strategies and vegetation processes. Wiley, Chichester. 222 pp.

Harper, J. L., 1977. Population biology of plants. Academic Press. London.

Hodgson, J. \& Grant, S. A., 1981. Grazing animals and forage resources in the hills and uplands. In: J. Frame (ed.). The Effective Use of Forage and Animal Resources in the Hills and Uplands, pp. 41-57. Occ. Symp. $12 \mathrm{Br}$. Grassl. Soc.

Hunter, R. F., 1962. Hill sheep and their pasture: a study of sheep-grazing in south-east Scotland. J. Ecol. 50: 651-680.

Huston, M., 1979. A general hypothesis of species diversity. Amer. Nat. 113: 81-101.

Job, D. A.\& Taylor, J. A., 1978. The production, utilization and management of upland grazings on Plynlimon, Wales. $J$. Biogeogr. 5: 173-191.

Klapp, E., 1965. Grünlandvegetation und Standort. Parey, Berlin.

Klötzli, F., 1965. Qualität und Quantität der Rehäsung in Waldund Grünland-Gesellschaften des nördlichen Schweizer Mittellandes. Veröff. Geob. Inst. Eidg. Techn. Hochschule Stiftung Rübel. 38: 1-186.

Langlands, K. P. \& Bennett, I. L., 1973a. Stocking intensity and pastoral production. 1 . Changes in the soil and vegetation of a sown pasture grazed by sheep at different stocking rates. J. Agric. Sci. (Camb.) 81: 193-204.

Langlands, K. P.\& Bennett, I. L., 1973b. Stocking intensity and pastoral production. II. Herbage intake of Merino sheep grazed at different stocking rates. J. Agric. Sci. (Camb.) 81: 205-209.

Leege, T. A., Herman, D. J.\& Zamora, B., 1981. Effects of cattle grazing on mountain meadows in Idaho. J. Range Manage. 34: $324-328$.

Leeuwen, C. G. van \& Maarel, E. van der, 1971. Pattern and process in coastal dune vegetations. Acta Bot. Neerl. 20: 191-198.

Mattson, W. J., Jr., 1980. Herbivory in relation to plant nitrogen content. Ann. Rev. Ecol. Syst. 11: 119-161.

Molgaard, P., 1977. Competitive effect of grass on establish- ment and performance of Taraxacum officinale. Oikos 29: 376-382.

Nicholson, J. A., Paterson, I. S. \& Currie, A., 1970. A study of vegetational dynamics: selection by sheep and cattle in Nardus pasture. In: A. Watson (ed.). Animal Populations in Relation to their Food Resources, pp. 129-143. Symp. Br. Ecol. Soc. Blackwell, Oxford.

Norman, M. J. T., 1957. The influence of various grazing treatments upon the botanical composition of a downland permanent pasture. J. Brit. Grassl. Soc. 12: 246-256.

Oosterveld, P., 1975. Beheer en ontwikkeling van natuurreservaten door begrazing. Natuur en Landschap 29: 161-171.

Pigott, C. D., 1956. The vegetation of upper Teesdale in the North Pennines. J. Ecol. 44: 545-586.

Regnèll, G., 1980. A numerical study of successions in an abandoned, damp calcareous meadow in S Sweden. Vegetatio 43 : 123-130.

Research Institute for Nature Management, 1979. Natuurbeheer in Nederland; Levensgemeenschappen. Pudoc, Wageningen.

Stobbs, T. H., 1973. The effect of plant structure on the uptake of tropical pastures. II. Differences in sward structure, nutrition value, and bite size of animals grazing Setaria anceps and Chloris gayana at various stages of growth. Austr. J. Agric. Res. 24: 821-829.

Veldman, D., 1983. De invloed van verschillende beheersmaatregelen op de grasland- en heidevegetatie van het Westerholt. Intern. Rep. Dept. of Plant Ecology, University of Groningen/Research Institute for Nature Management, Leersum (mimeo). $75 \mathrm{pp}$.

Wiegolaski, F. E., 1976. The effect of herbage intake by sheep on primary production, ratios top-root and dead-live aboveground parts (Hardangervidda, Norway). Pol. Ecol. Stud. 2: 67-76.

Willms, W., Bailey, A. W. \& McLean, A., 1980. Effect of burning or clipping Agropyron spicatum in the autumn on the spring foraging behaviour of mule deer and cattle. J. Appl. Ecol. 17: 69-84.

Witschi, P. A. \& Michalk, D. L., 1979. The effect of sheep treading and grazing on pasture and soil characteristics of irrigated annual pastures. Austr. J. Agric. Res. 30: 741-750.

Accepted 5.9.1983. 